Special issue of the 3rd International Conference on Computational and Experimental Science and Engineering (ICCESEN 2016)

\title{
Ecophysiological Effects of Porsuk River's Water and Boron Mine Wastewater on Cucumis Sativus L. Seeds
}

\author{
G. IŞIK* AND M. ÇALISEKI \\ Anadolu University, Faculty of Science, Biology Department, Eskişehir, Turkey
}

\begin{abstract}
Pure water resources are decreasing dramatically and wastewater treatment, to be able to reuse water, is highly crucial for this ecological issue. In this study, Porsuk River was chosen as a wastewater source, with its polluted water, taken from pre-determined stations outside the city. Water with higher concentrations of boron was obtained from boron mine wastewater. Boron is a low-abundance element essential for plant growth, which depending on concentration, can be considered as both a nutritional and toxic element. The experimental organism of Cucumis sativus L. (Beith alpha variety) was used to show the effects of wastewater applications on seedling development by measuring stem-root length and biomass. In conclusion, river water and boron mine wastewater treatments have no inhibitory effects on the growth and biomass of Cucumis sativus seeds statistically. This practical and low-cost method can be used in agriculture, where wastewater can be used without further processing. We can say that Cucumis sativus can be cultivated in boron polluted areas as a boron tolerant plant.
\end{abstract}

DOI: 10.12693/APhysPolA.132.746

PACS/topics: 88.20.dh, 88.2.D-, 87.19.lx

\section{Introduction}

Boron is an essential micronutrient and plays an important role in cell wall structure, membrane stability, sugar transportation, and phenol, carbohydrate, nucleic acid and indole acetic acid metabolism [1]. Boron has a great impact on reproductive structure development and on seed development [1]. Turkey has the largest boron reserve in the world and is one of the leading countries, regarding the boron mining [2-7]. Boron reserves of Turkey are found in Western Anatolia, and main reserves are located in Kırka (Eskisehir) and a few cities [8-11]. There are a few plant species known, which are tolerant to boron. Cultivars, known for B-tolerance, are barley [12], Puccinellia distans and Gypsophila arrostii [13].

In recent years, growing water constraint has become a big problem, with a decrease in water quality and water quantity [14]. Using recycled waste water seems to solve irrigation water need of local habitants. Although salinity does not seem to be a factor limiting crop production, irrigation with recycled waste water can accelerate natural soil salinization processes in regions where desertification is of particular concern [15]. A large part of the urban waste water in many residential areas, without being subjected to any treatment or low degrees of purification is released into rivers and streams that are used for irrigation of agricultural areas [16]. Rapidly growing population, urbanization, widespread use of fertilizers and pesticides in agricultural areas lead to rapid contamination of limited freshwater resources [16, 17]. Because of drought, especially for irrigation, the introduction of alternative water sources instead of using a good quality water is extremely important [16, 18].

*corresponding author; e-mail: glcnylmz@gmail.com
Irrigation water demand of Eskisehir district is mainly satisfied using waters from Porsuk River, for agricultural uses. Cucumis sativus is one of the most common plants cultivated in Turkey. Although at first glance it appears to be of little importance for human nutrition, Cucumis sativus is rich in vitamins, enzymes and plant mineral substances [16]. The aims of this study were to observe ecophysiological effects of Porsuk River's water and boron mine wastewater on Cucumis sativus $\mathrm{L}$. seeds in terms of seedling development (stem and root length) and biomass $(\mathrm{g} / \mathrm{ha})$ and finding out whether Cucumis sativus could be a boron tolerant plant or not.

\section{Materials and methods}

In this study, for germination of Cucumis sativus seeds (experimental material), pure water (as control), undiluted water from Porsuk River and diluted boron mine waste water, which have different concentrations of boron $(8,16,32$ and $64 \mathrm{ppm})$ were used. For each application, the seeds were germinated in seed beds which contain 10 seeds, $9 \mathrm{~cm} \varnothing$ Petri dishes, double layered filter paper, using a 16 hours light/8 hours dark photoperiod, at $25 \pm 1{ }^{\circ} \mathrm{C}$, in a climate chamber (Sanyo, MLR 350), for 21 days. The germination experiments were carried out tetraplicate. When a radicle did touched the seed bed, it was accepted as a germinated seed. The number of germinated seeds was recorded at the germination table every day. Stem and root length of seedlings were measured by ruler and callipers, root and shoot biomass were measured by analytical balance and calculated using the following formula

$$
B=\left(W_{\mathrm{f}}-W_{\mathrm{w}}\right) / S,
$$

where $B$ is biomass; $W_{\mathrm{f}}$ is fresh weight $(\mathrm{g}), W_{\mathrm{w}}$ is water weight (g) and $S$ is area (ha). For evaluation of the results obtained from the experiments, the "one way ANOVA test" was applied [19]. 


\section{Results}

Seedling growth and biomass data are presented in Table I. For stem elongation $(F=2.086, d f=5.18$, $P>0.05)$, root elongation $(F=0.833, d f=5.18$, $P>0.05)$, stem biomass $(F=0.791, d f=5.18$, $P>0.05)$ and root biomass $(F=1.667, d f=5.18$, $P>0.05)$ data, no statistically significant difference was found between groups.

TABLE I

Seedling growth and biomass data after different water resource applications.

\begin{tabular}{c|c|c|c|c}
\hline \hline Application & $\begin{array}{c}\text { Stem } \\
\text { length } \\
{[\mathrm{cm}]}\end{array}$ & $\begin{array}{c}\text { Root } \\
\text { length } \\
{[\mathrm{cm}]}\end{array}$ & $\begin{array}{c}\text { Stem } \\
\text { biomass } \\
{[\mathrm{g} / \mathrm{ha}]}\end{array}$ & $\begin{array}{c}\text { Root } \\
\text { biomass } \\
{[\mathrm{g} / \mathrm{ha}]}\end{array}$ \\
\hline Control & 8.79 & 9.61 & 3442.14 & 630.46 \\
River water & 8.75 & 11.77 & 4011.57 & 475.82 \\
8 ppm B & 6.14 & 10.41 & 3541.45 & 359.38 \\
16 ppm B & 8.99 & 11.53 & 3526.48 & 535.49 \\
32 ppm B & 8.15 & 12.09 & 3559.44 & 535.42 \\
64 ppm B & 7.64 & 11.59 & 3592.34 & 542.41
\end{tabular}

For Cucumis sativus seedlings, the experimental results of boron, river water and control applications were similar (Figs. 1 and 2).

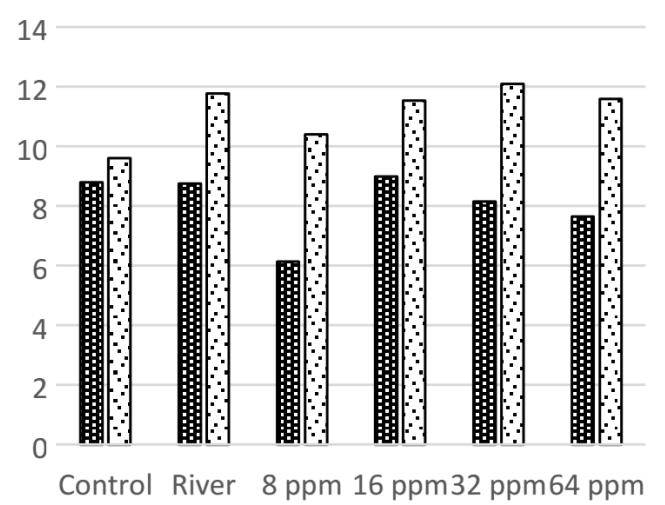

Fig. 1. Seedling development of Cucumis sativus seeds under different waste water treatments.

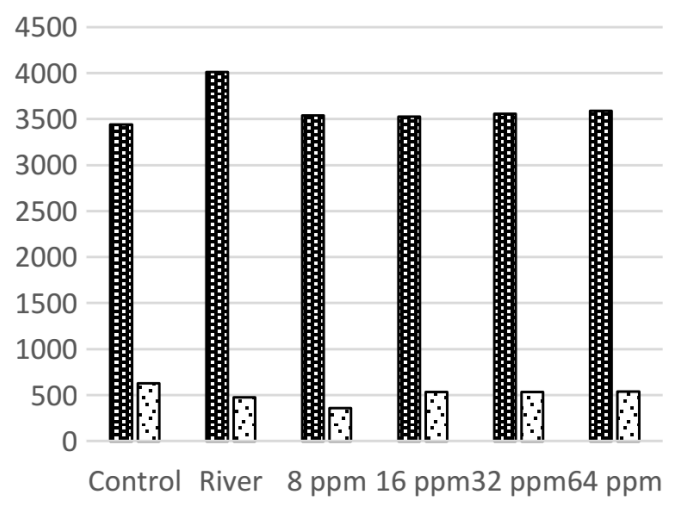

Fig. 2. Stem and root biomass of Cucumis sativus seeds under different waste water treatments.

\section{Conclusions}

High concentrations of boron in soils and irrigation water are toxic to plants [20] and restrict agricultural activities in polluted places [21, 22]. However, Cucumis sativus (var. Beith alpha) seems to be a very tolerant plant with respect to boron presence, treatment with up to $64 \mathrm{ppm}$ of $\mathrm{B}$ has no inhibitory effects on seedling development and biomass.

Boron toxicity is crop-specific; it generally leads to chlorosis and necrosis, starting at the edges of mature leaves $[3,9]$. In this study, no leaf injuries or damages were observed on leaves of Cucumis sativus seedlings because of boron toxicity.

It is known that boron tolerance and accumulation varies widely between different plant species and/or cultivars [23]. Nevertheless, the molecular basis of these processes is not well-understood [24]. Finding the genes involved in boron tolerance is valuable for the future development of boron-tolerant crops or boron-accumulating plants for phytoremediation strategies [22].

It can be said that Beith alpha variety of Cucumis sativus taxon could be one of boron-tolerant or boronaccumulating plants, because of its high tolerance against increasing boron concentrations. Boron deficiency affects the reproductive yield more than biomass yield, even in the absence of any visible sign of deficiency symptoms and therefore the requirement of $\mathrm{B}$ for reproductive development appears to be more for reproductive development than for vegetative growth [1].

According to our study, biomass of seedlings was not affected significantly in a positive or negative way, under increasing boron concentrations, similarly to Pandey and Gupta's [1] findings. Cucumis sativus can be cultivated in boron polluted areas as a boron tolerant plant.

\section{References}

[1] N. Pandey, B. Gupta, J. Trace Elem . Med. Biol. 27, 58 (2013).

[2] C. Türe, R.W. Bell, Israel J. Pl. Sci. 52, 125 (2004).

[3] O.C. Türker, C. Ture, H. Bocuk, A. Yakar, Int. J. of Phytorem. 16, 537 (2014).

[4] M. Davraz, Acta Phys. Pol. A 128, B-26 (2015).

[5] B. Buyuk, A.B. Tugrul, M. Cengiz, O. Yucel, G. Goller, F.C. Sahin, Acta Phys. Pol. A 128, 132 (2015).

[6] A. Akkas, A.B. Tugrul, B. Buyuk, A.O. Addemir, M. Marsoglu, B. Agacan, Acta Phys. Pol. A 128, 176 (2015).

[7] M. Cengiz, S.C. Ozer, B. Buyuk, A.B. Tugrul, O. Yucel, G. Goller, F.C. Sahin, Acta Phys. Pol. A 128, 187 (2015).

[8] R.B. Kistler, C. Helvaci, Boron and borates in: Industrial Minerals and Rocks, 6th ed., Ed. D.D. Carr, Society of Mining, Metallurgy and Exploration, 1994, p. 171.

[9] H. Böcük, A. Yakar, O.C. Türker, Ecological Indicators 29, 538 (2013). 
[10] D. Sarıyer, R. Küçer, N. Küçer, Acta Phys. Pol. A 128, B-201 (2015).

[11] Ü. Kara, H.O. Tekin, A. Calik, İ. Akkurt, Acta Phys. Pol. A 128, B-335 (2015).

[12] K. Miwa, J. Takano, H. Omori, M. Seki, K. Shinozaki, T. Fujiwara, Science 318, 1417 (2007).

[13] A.R. Stiles, D. Bautista, E. Atalay, M. Babaoğlu, N. Terry, Environ. Sci. Technol. 44, 7089 (2010).

[14] Ö. Aksoy, T. Erbulucu, E. Vatan, J. App. Bio. Sci. 5, 75 (2011).

[15] M. Dorta-Santos, M. Tejedor, C. Jiménez, J.M. Hernández-Moreno, F.J. Díaz, Agri. Water Manag. 171, 142 (2016).

[16] M. Çalıseki, G. Işık, S. Leblebici, Anadolu Univ. J. Sci. Technol.-C 4, 77 (2016).

[17] E. Yucel, G. Yılmaz, Gazi Univ. J. Sci. 22, 123 (2009).

[18] R.I. Al-Dulaimi, N. Ismail, M.H. Ibrahim, Int. J. Sci. Res. 2, 1 (2012).
[19] H. Altuntaş, Acta Phys. Pol. A 128, B-182 (2015).

[20] R.O. Nable, G.S. Banuelos, J.G. Paull, Plant Soil 193, 181 (1997).

[21] B. Cartwright, B. Zarcinas, A. Mayfield, Aust. J. Soil Res. 22, 261 (1984).

[22] C.P. Rámila, S.A. Contreras, C. Di Domenico, M.A. Molina-Montenegro, A. Vega, M. Handford, C.A. Bonilla, G.E. Pizarro, J. Haz. Mater. 317, 476 (2016).

[23] R.E. Ferreyra, A.U. Aljaro, R.S. Ruiz, L.P. Rojas, J. Oster, Agric. Water Manag. 34, 111 (1997).

[24] M.P. Princi, A. Lupini, F. Araniti, C. Longo, A. Mauceri, F. Sunseri, M.R. Abenavoli, Boron toxicity and tolerance in plants: recent advances and future perspectives A2 - Ahmad, Parvaiz, in: Plant Metal Interaction, Ch. 5, Elsevier, 2016, p. 115. 